\title{
Changes in Soil Carbon Stocks under Integrated Crop-Livestock-Forest System in the Brazilian Amazon Region
}

\author{
Marcela C. G. da Conceição ${ }^{1}$, Eduardo S. Matos ${ }^{2}$, Edison D. Bidone ${ }^{1}$, \\ Renato de A. R. Rodrigues ${ }^{3}$, Renato C. Cordeiro ${ }^{1}$ \\ ${ }^{1}$ Universidade Federal Fluminense, Niterói, Brazil \\ ${ }^{2}$ Embrapa Agrossilvipastoril, Sinop, Brazil \\ ${ }^{3}$ Embrapa Solos, Rio de Janeiro, Brazil \\ Email: *eduardo.matos@embrapa.br
}

How to cite this paper: da Conceição, M.C.G., Matos, E.S., Bidone, E.D., de A. R. Rodrigues, R. and Cordeiro, R.C. (2017) Changes in Soil Carbon Stocks under Integrated Crop-Livestock-Forest System in the Brazilian Amazon Region. Agricultural Sciences, 8, 904-913.

https://doi.org/10.4236/as.2017.89066

Received: July 17, 2017

Accepted: August 31, 2017

Published: September 5, 2017

Copyright $\odot 2017$ by authors and Scientific Research Publishing Inc. This work is licensed under the Creative Commons Attribution International License (CC BY 4.0).

http://creativecommons.org/licenses/by/4.0/

\begin{abstract}
Several studies indicate that the use of integrated production systems, such as integrated crop-livestock-forest systems (ICLF), improves the quality of the soil and consequently the sequestration of organic carbon in the soil. In this way, this work aims to evaluate the carbon stocks in soil under different management systems in the Cerrado/Amazonia transition zone, namely: ICLF, no-tillage, pasture and eucalyptus plantation. For this, two soil samplings were done in 2011 and 2014, in the $0-5,5-10$ and $10-30 \mathrm{~cm}$ layers. Soil carbon and nitrogen stocks were analyzed. ICLF system was the treatment that obtained the highest percentage of carbon gain (7.8\%) after three years of establishment which represents to an increase of $5.5 \mathrm{Mg} \cdot \mathrm{ha}^{-1}$. Management systems, such as ICLF, with minimal soil disturbance combined with crop rotations that contribute to the quantity and quality of residues input, increase soil organic matter content. Carbon stock data show the potential of ICLF systems to increase soil carbon stocks.
\end{abstract}

\section{Keywords}

Agriculture, Soil Carbon, ICLF, Soil Management

\section{Introduction}

Until the end of the last century, agriculture development was based on the expansion of new areas for cultivation, leading to the deforestation of large areas of native forests and natural ecosystems [1], resulting in losses of environmental 
services. According to [2], approximately 55 to $90 \mathrm{Pg}$ of soil C have been lost from managed areas since the advent of agriculture, being one of the main causes of degradation and consequent decline of soil fertility.

As described by [3] and [4], while ensuring food security, there is an urgent need to reduce the impact of food production on the climate [5] and to improve the resilience of food production to future environmental changes [6], [7]. According to the projections of the Intergovernmental Panel on Climate Change (IPCC), the agricultural sector will be greatly affected by global climate change with impacts on its productivity, management and spatial distribution of crops. Thus, it is necessary to change the paradigm of agriculture with the use of management practices that favor the positive balance of physical and chemical attributes of the soil, such as increasing of $\mathrm{C}, \mathrm{N}$, water retention, reduction of soil loss by erosion and leaching.

During UNFCCC COP 15 ( $15^{\text {th }}$ Conference of the Parties under United Nations Framework Convention on Climate Change) in Copenhagen, Brazil undertakes a voluntary national commitment to reduce GHG emissions. This commitment was to reduce by $36.1 \%$ and $38.9 \%$ the 2020 projected emissions. With this, Brazil will mitigate between 975 million and 1 billion tons of carbon dioxide by 2020 . For The fulfillment of the commitment, the Brazilian government created several mitigation and adaptation plans for different sectors of the economy, among them are the Low Carbon Agriculture Plan.

The GHG emission reduction potential of this plan is approximately 150 million $\mathrm{Mg} \mathrm{CO}_{2} \mathrm{e}$, and does not consider the potential for removal from the forest plan. This plan corresponds to seven programs, six of which are related to mitigation technologies, and a last program with actions to adapt to climate change: Recovery of Degraded Pastures; Integrated Crop-Livestock-Forest System (ICLF) and Agroforestry Systems (AFs); No-Tillage System (NT); Biological Nitrogen Fixation (BNF); Planted Forests; Animal Waste Treatment; and Climate Change Adaptation.

In addition to this, Brazil has made a new commitment for the NDC (Nationally Determined Contributions) under Paris Agreement (UNFCCC COP21) to implement more 15 million hectares for recovery of degraded pastures and 5 million hectares of ICLF systems by 2030, confirming the potential of these technologies to mitigate greenhouse gases emissions and develop a low carbon agriculture in Brazil.

In agricultural soils, the carbon stocks are affected by changes in land use systems or management practices. Thus, the adoption of more sustainable management systems, such as ICLF, emerges as an alternative to conventional farming systems, with great potential to promote improvements in soil quality, especially with regard to the increase carbon stocks in the short- and long-term [8] [9] [10] [11] [12]. Tee-based systems are expected to have better soil C sequestration potential than most row crop agricultural systems [13]. At the same time, appropriate pasture management may affect soil $\mathrm{C}$ balance under ICLF systems 
and contribute to increase soil carbon stocks, because of higher biomass production associated with deep root systems while increasing physical protection of soil organic matter (SOM) against mineralization.

Soil organic matter (MOS) plays an important role in maintaining agricultural productivity. The accumulation of MOS promotes improvements in the physical, biological and chemical soil properties, allowing an increase in productivity and reduction of expenses with irrigation, fertilizers, soil conditioners and other agricultural inputs. Understanding how MOS behaves in different types of management is essential for the direction of public policies aimed at the dissemination of agricultural practices that increase the stocks of soil organic $\mathrm{C}$ and reduce GHG emissions.

\section{Material and Methods}

The sampling areas were located on experimental field at the Embrapa Agrosilvopastoral Research Center ( $11^{\circ} 51^{\prime} \mathrm{S}, 55^{\circ} 35^{\prime} \mathrm{W} ; 384 \mathrm{~m}$ asl) in Sinop, State of Mato Grosso, Brazil. The mean annual temperature is $25^{\circ} \mathrm{C}$ and mean annual rainfall is $2.550 \mathrm{~mm}$ [14]. The soil of the experimental site is classified as a Red Yellow Latosol (Oxisol) [15], a Udox [16]. The soil is a well-drained clay (32\% sand, $56 \%$ clay), with non-hydromorphic characteristics. The top $0-20 \mathrm{~cm}$ layer has the following properties: $\mathrm{pH}\left(\mathrm{H}_{2} \mathrm{O}\right)=5.6 ; \mathrm{CEC}=7.5 \mathrm{cmol}_{\mathrm{c}} \mathrm{kg}^{-1} ; \mathrm{Ca}^{2+}=2.5$ $\mathrm{cmol}_{c} \cdot \mathrm{kg}^{-1} ; \mathrm{Mg}^{2+}=0.81 \mathrm{cmol}_{c} \cdot \mathrm{kg}^{-1} ; \mathrm{K}^{+}=0.19 \mathrm{cmol}_{\mathrm{c}} \cdot \mathrm{kg}^{-1} ; \mathrm{P}=14.3 \mathrm{mg} \cdot \mathrm{kg}^{-1}$.

The experimental area was cleared of its native vegetation in 1984 for cultivation of cassava (Manihot esculenta Crantz) [17]. Any additional deforestation was stopped during the 2000s. [18] reported that rice (Oryza sativa L.) was cultivated on this land during the early 1990s, followed by soybean [Glycine max (L.) Merril]. Between 2002 and 2007, soybeans and maize (Zea mays L.) were incorporated into the conventional system.

During the 2007/2008 and 2008/2009 crop seasons, subsequently, the soybean and cotton (Gossypium hirsutum L.) successions were followed. During the $2009 / 2010$ and 2010/2011 crop seasons the area was left fallow. In November 2011, subsoiling (chisel plowing to $40 \mathrm{~cm}$ depth) was done to alleviate compaction.

The experiment was then established in 2011 and comprised the following treatments: 1) Eucalyptus plantation (Eucalyptus urograndis, clone H13); 2) No-tillage system with soybean "BRSGO 8560RR" followed by corn (Z. mays) intercropped with Urochloa brizanta; 3) Pasture of U. brizanta "Marandu"; and 4) ICLF-integrated crop-livestock-forest system, comprising of three rows of eucalyptus (E. urograndis), soybean followed by corn ( $Z$. mays) intercropped with $U$. brizanta cultivated between tree rows. An area under Native Forest was used as a reference.

Soil samples were taken from $0-5,5-10,10-30 \mathrm{~cm}$ layers were obtained in 2011 and 2014 for determination of total C and N content. Each replicate was obtained of four subsamples bulked together. Samples were air dried, sieved 
through a 2-mm sieve, then further ground by a mill to pass through a $0.106 \mathrm{~mm}$ sieve and analyzed for total $\mathrm{N}$ and $\mathrm{C}$ concentrations by dry combustion (Vario Macro, Elementar Analysensysteme, Hanau, Alemanha) [19].

Soil cores $\left(100 \mathrm{~cm}^{3}\right)$ were also collected from $0-5,5-10$ and $10-20 \mathrm{~cm}$ layers to evaluate soil bulk density $(B D)$. The $\mathrm{C}$ and $\mathrm{N}$ stocks for each depth, were determined according to [20]:

$$
Y_{\text {stock }}\left(\mathrm{Mg} \cdot \mathrm{ha}^{-1}\right)=X \times B D \times \operatorname{th} \times(1-S) \times 10^{-1}
$$

where $X$ is the $\mathrm{C}$ or $\mathrm{N}$ concentrations $\left(\mathrm{g} \mathrm{kg}^{-1}\right) ; B D$ is the bulk density $\left(\mathrm{Mg}^{-3} \mathrm{~m}^{-3}\right)$, th is the thickness of the soil layer $(\mathrm{cm})$, and $S$ is the stone content.

The amounts of carbon and nitrogen stocks were corrected by the equivalent mass method [21]:

$$
C s / N s=\sum_{i=1}^{n-1} C / N_{T i}+\left[M_{T n}-\left(\sum_{i=1}^{n} M_{T i}-\sum_{i=1}^{n} M_{S i}\right)\right] C / N_{T n}
$$

where $C s / N s$ correspond to the stock of carbon or nitrogen $\left(\mathrm{Mg} \cdot \mathrm{ha}^{-1}\right)$ in the soil to a depth equivalent to the reference. $\sum_{i=1}^{n-1} C / N_{T i}$ the sum of the total content of carbon present in the first layer to the penultimate layer $(n-1)$ evaluated treatment. $M_{T n}$ the corresponding soil mass last layer of the estimated treatment. $\sum_{i=1}^{n} M_{T i}$ the sum soil mass of the first to the last layer of the evaluated treatment. $\sum_{i=1}^{n} M_{S i}$ the sum of the soil mass first to the last layer of the reference area and $C / N_{T n}$ the $\mathrm{C}$ or $\mathrm{N}$ concentrations $\left(\mathrm{Mg} \cdot \mathrm{Mg}^{-1}\right)$ in the last layer of the evaluated treatment.

Comparison of means was done by using standard errors values and the differences were attributed to the management systems, since evaluated treatments and Native Forest area presented similar soil type and topography.

\section{Results and Discussion}

Total carbon concentrations varied from 17.2 to $38.4 \mathrm{~g} \cdot \mathrm{kg}^{-1}$ (Figure 1). From 2011 to the end of 2014, changes in the contents of C and N were observed only in the uppermost soil layer $(0-5 \mathrm{~cm})$. However, the observed carbon values did not differ from 2011 and 2014 among the evaluated treatments.

After three years of cultivation, ICLF presented the highest increase of carbon concentration (15\%) in the $0-5 \mathrm{~cm}$ layer, followed by Eucalyptus (13\%), Pasture (9\%) and No-tillage (8\%). Except for Eucalyptus, management systems also contribute to increase total nitrogen, in the $0-5 \mathrm{~cm}$ layer. However, the increase in total nitrogen in all investigated soil layers was only observed for ICLF. The increase in total carbon concentration is probably related to the higher inputs of vegetal residues in the surface layer. Especially in the ICLF system, higher residues input were probably due to the combination of tree, pasture and crop in the same area. This higher availability of total carbon and nutrients, mainly in the 

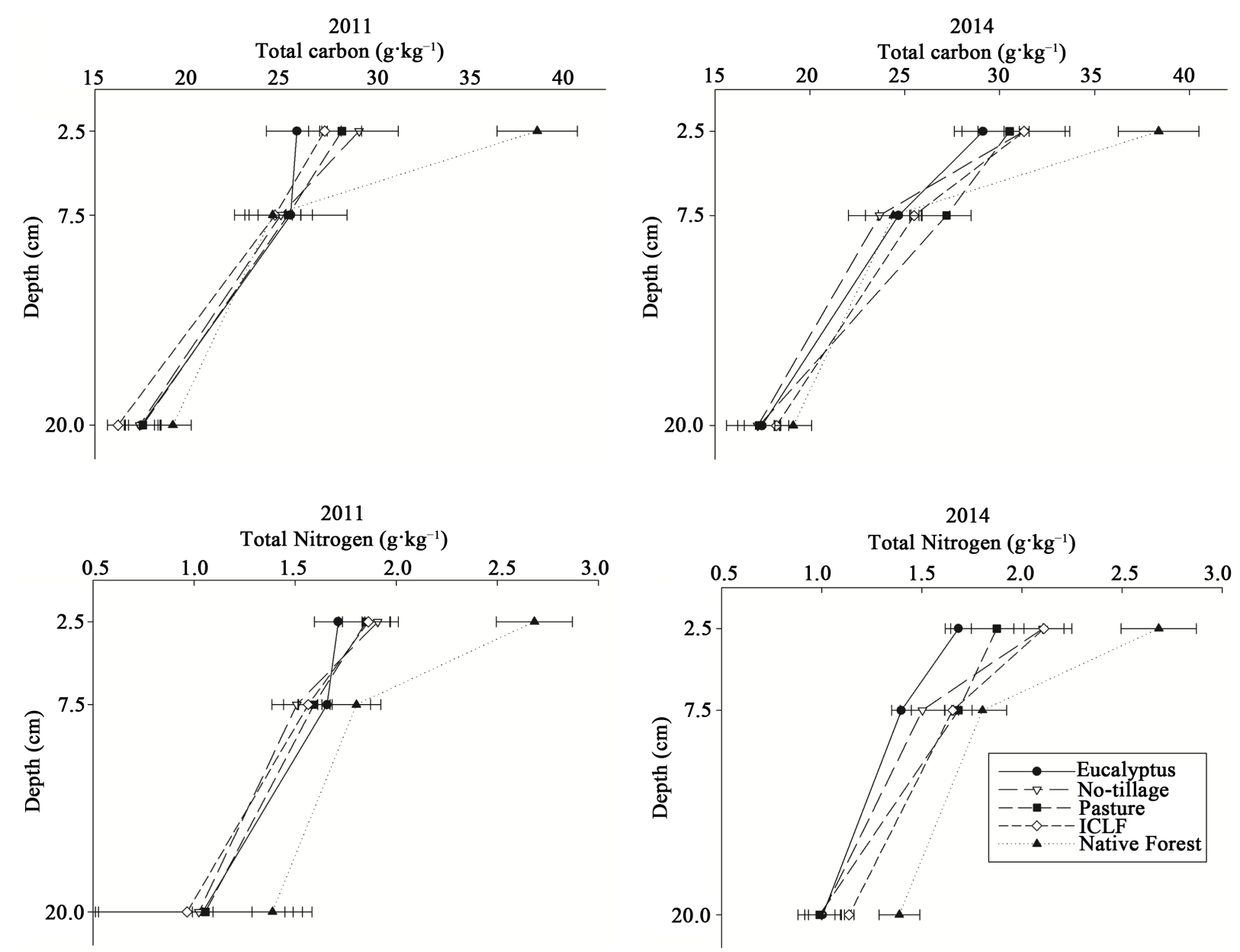

Figure 1. Total C and N concentrations in the 0 - 5, 5- 10 and $10-30 \mathrm{~cm}$ layers in soils under Eucalyptus plantation; No-tillage; Pasture; ICLF-integrated crop-livestock-forest system and Native Forest. Horizontal bars represent the standard error $(\mathrm{n}=4)$.

soil surface layer $(0-5 \mathrm{~cm})$ could contribute to higher amounts of microbial biomass and activity promoted by ICLF system.

ICLF and Pasture showed the highest total C stock in the $0-30 \mathrm{~cm}$ layer. Nitrogen stocks followed the same trend of carbon, however only ICLF presented the highest nitrogen stock (Figure 2). Soil carbon stocks values observed in 2014 for Pasture $\left(71 \mathrm{Mg} \cdot \mathrm{ha}^{-1}\right)$ and ICLF $\left(70 \mathrm{Mg} \cdot \mathrm{ha}^{-1}\right)$ were similar to that found in the Native Forest $\left(75 \mathrm{Mg} \cdot \mathrm{ha}^{-1}\right)$.

Three years of ICLF promoted changes in soil C and N stocks (Table 1). Despite the similar values of carbon stocks in soil under Pasture and ICLF treatments, after three years, ICLF contribute to increase total carbon stock by 5.5 $\mathrm{Mg} \cdot \mathrm{ha}^{-1}$ in the $0-30 \mathrm{~cm}$ layer. This result indicates that ICLF could be promising to improve soil carbon sequestration and nutrient cycling.

According to [22], significant increase in soil C stocks is only possible under a management system that reduces degradation of soil organic matter as well as contributes to increase $\mathrm{N}$ in the soil-plant system. In the ICLF system, pasture contributes to great amounts of high $\mathrm{C} / \mathrm{N}$ ratio residues, providing an increase in 

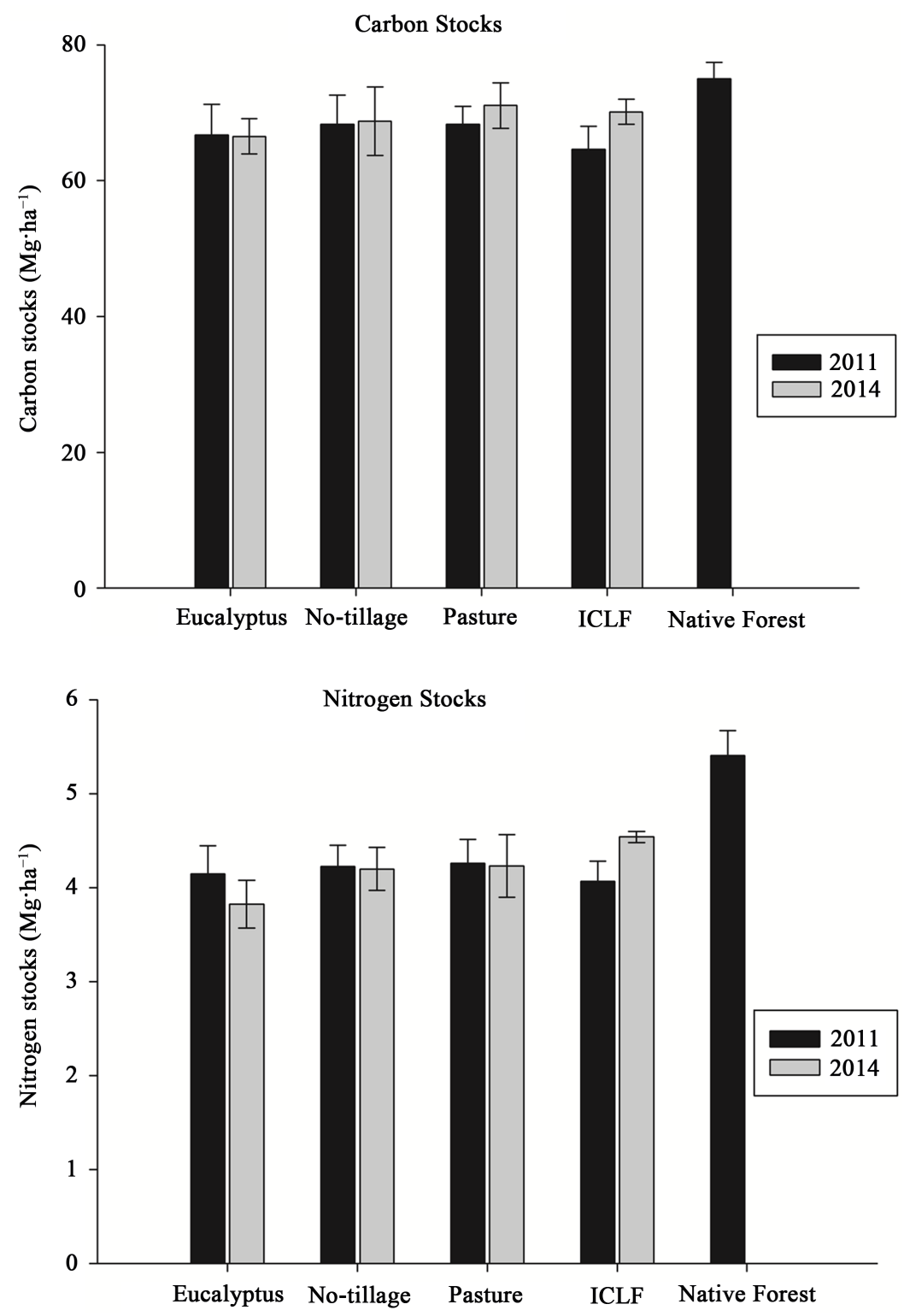

Figure 2. Total C and $\mathrm{N}$ stocks in the top $0-30 \mathrm{~cm}$ layers in soils under Eucalyptus plantation; No-tillage; Pasture; ICLF-integrated crop-livestock-forest system and Native Forest. Vertical bars represent the standard error $(n=4)$.

Table 1. Gains and losses in soil C and N stocks of different management systems after three years establishment.

\begin{tabular}{ccccc}
\hline \multirow{2}{*}{$\begin{array}{c}\text { Soil layer } \\
(\mathrm{cm})\end{array}$} & Eucalyptus & No-tillage & Pasture & ICLF \\
\cline { 2 - 5 } $0-30$ & -0.3 & +0.6 & +3.9 & +7.8 \\
& & Gains and losses in soil nitrogen (\%) & \\
& & No-tillage & Pasture & ICLF \\
$0-30$ & -8.3 & -0.7 & -0.6 & +10.4 \\
\hline
\end{tabular}

(-) Losses; (+) Gains. 
the persistence of soil cover. However, high $\mathrm{C} / \mathrm{N}$ ratio residues could reduce $\mathrm{N}$ availability for crops [11], [23], [24].

On the other hand, leguminous crops in the rotation system, such as soybeans, can provide a significant source of $\mathrm{N}$ for the subsequent crops [25]. [10] attributed the increase of total carbon in soil under crop-livestock integration systems to the combination of maize with brachiaria. According to the authors, higher deposition of plant residues combined with slower degradation rate of the residues could contribute to increase soil organic matter. On this context, brachiaria call attention, because of the well-developed root system, distributed along the soil profile.

Additionally, the tree component (eucalyptus) in the ICLF system is also an important carbon sink, because of its high potential to accumulate large amounts of carbon in the woody biomass and to provide more recalcitrant residues [26]. [27] observed that ICLF promoted higher carbon stocks when compared to an integrated crop-livestock system, no-tillage and native vegetation, not only in the surface layer, but also in deep soil layers $(1 \mathrm{~m})$. The higher carbon stocks observed for ICLF was attributed to the deposition of the crop residues on the soil surface, but also the greater amounts of residues provided by pasture and trees in deeper soil layers.

According to [28], the highest concentration of C in the soils under ICLF systems is likely due to the combination of pasture and forest on the same area, since both ICLF components have high capacity to accumulate carbon in deeper soil layers through accretion and deposition of organic material resistant to degradation.

Combined with minimal soil disturbances that favor carbon protection [8], [29], all these mentioned benefits provide by ICLF systems could contribute to the increase of soil carbon stocks. [30] and [31] suggested that the use of legumes, combined with a greater diversity of species in succession or crop rotation, such as the ICLF, significantly increase $\mathrm{C}$ and $\mathrm{N}$ retention in the soil, with important implications for the balance of both elements on a regional and global scale and for sustainable production and environmental quality.

In addition, ICLF systems are the target of public policies to promote a more sustainable and resilient agriculture to climate change in Brazil. The data of this work show that ICLF promotes improvements in the chemical, physical and biological soil conditions, besides promoting increases of the $\mathrm{CO}_{2}$ removal from the atmosphere, through tree growth and soil carbon accumulation.

\section{Conclusion}

After three years establishment, the integrated crop-livestock-forest system showed the highest potential of soil carbon sequestration with values similar of those found under Native Forest. Thus, we consider that ICLF could be an important tool to help Brazil meet its voluntary greenhouse gas emission targets in COP15, especially in agriculture sector. 


\section{Acknowledgements}

This research was supported by $\mathrm{CNPq}$, Inter-American Development Bank (IDB-"Projeto Rural Sustentável”) and Embrapa. We thank R. Chelegão and R. Bicudo for technical assistance with laboratory analyses and Fluminense Federal University and Embrapa for technical support.

\section{References}

[1] Alexandratos, N. and Bruinsma, J. (2003) Introduction and Overview. In: Bruinsma, J., Ed., World Agriculture: Towards 2015/2030, an FAO Perspective, Earthscan Publications, London, 1-28.

[2] Lal, R. (2006) Enhancing Crop Yields in the Developing Countries through Restoration of the Soil Organic Carbon Pool in Agricultural Lands. Land Degradation \& Development, 17, 197-209. https://doi.org/10.1002/ldr.696

[3] Smith, P. and Gregory, P.J. (2013) Climate Change and Sustainable Food Production. The Proceedings of the Nutrition Society, 72, 21-28.

https://doi.org/10.1017/S0029665112002832

[4] Foley, J.A., et al. (2011) Solutions for a Cultivated Planet. Nature, 478, 337-342. https://doi.org/10.1038/nature10452

[5] Lal, R. (2004) Soil Carbon Sequestration Impacts on Global Climate Change and Food Security. Science, 304, 1623-1627. https://doi.org/10.1126/science.1097396

[6] Smith, P., et al. (2013) How Much Land-Based Greenhouse Gas Mitigation Can Be Achieved without Compromising Food Security and Environmental Goals? Global Change Biology, 19, 2285-2302. https://doi.org/10.1111/gcb.12160

[7] Smith, P. (2015) Malthus Is Still Wrong: We Can Feed a World of 9-10 Billion, but Only by Reducing Food Demand. The Proceedings of the Nutrition Society, 74, 187-190. https://doi.org/10.1017/S0029665114001517

[8] Bayer, C., Martin-Neto, L., Mielniczuk, J., Pavinato, A. and Dieckow, J. (2006) Carbon Sequestration in Two Brazilian Cerrado Soils under No-Till. Soil \& Tillage Research, 86, 237-245. https://doi.org/10.1016/j.still.2005.02.023

[9] Lovato, T., Mielniczuk, J., Bayer, C. and Vezzani, F. (2004) Carbon and Nitrogen Addition Related to Stocks of These Elements in Soil and Corn Yield under Management Systems. Revista Brasileira de Ciência do Solo, 28, 175-187. https://doi.org/10.1590/S0100-06832004000100017

[10] Gazolla, P.R., Guareschi, R.F., Perin, A., Pereira, M.G. and Rossi, C.Q. (2015) Labile and Recalcitrant Fractions of Soil Organic Matter under Integrated Crop-Livestock System. Semin. Ciências Agrárias, 36, 693. https://doi.org/10.5433/1679-0359.2015v36n2p693

[11] Da, R., Nicoloso, S., Lovato, T., Amado, T.J.C., Bayer, C. and Lanzanova, M.E. (2008) Soil Organic Carbon Budget under Crop-Livestock Integration in Southern Brazil. Revista Brasileira de Ciência do Solo, 32, 2425-2433.

[12] Batlle-Bayer, L., Batjes, N.H. and Bindraban, P.S. (2010) Changes in Organic Carbon Stocks upon Land Use Conversion in the Brazilian Cerrado: A Review. Agriculture, Ecosystems \& Environment, 137, 47-58. https://doi.org/10.1016/j.agee.2010.02.003

[13] Montagnini, F. and Nair, P.K.R. (2004) Carbon Sequestration: An Underexploited Environmental Benefit of Agroforestry Systems. Agroforestry Systems, 61-62, 281 295. https://doi.org/10.1023/B:AGFO.0000029005.92691.79 
[14] Souza, A.P., Mota, L.L., Zamadei, T., Martim, C.C., Almeida, F.T. and Paulino, J. (2013) Climate Classification and Climatic Water Balance in Mato Grosso State, Brazil. Nativa: Pesquisas Agrárias e Ambientais, 1, 34-43. https://doi.org/10.14583/2318-7670.v01n01a07

[15] Viana, J.H.M., Spera, S.T., Magalhaes, C.A.S. and Calderano, S.B. (2015) Soil Characterization of the Experimental Site of the Second Crop Project in Sinop-MT. Embrapa Milho e Sorgo, Sete Lagoas, 20 p.

[16] Soil Survey Staff (2006) Keys to Soil Taxonomy. 10th Edition, USDA-Natural Resources Conservation Service, Washington DC.

[17] de Araujo, R.A., da Costa, R.B., Felfili, J.M., Gonçalvez, I.K., de Sousa, R.A.T. and Dorval, A. (2009) Loristics and Structure of a Forest Fragment at a Transitional Zone at the Amazon in Mato Grosso State, Municipality of Sinop. Acta Amazonica, 39, 865-877. https://doi.org/10.1590/S0044-59672009000400015

[18] Diel, D., et al. (2014) Phosphorus Horizontal and Vertical Distribution in Single Soybean Crop and in Integrated Crop-Livestock-Forest Systems. Pesquisa Agropecuária Brasileira, 49, 639-647. https://doi.org/10.1590/S0100-204X2014000800008

[19] Nelson, D.S. and Sommers, L.E. (1996) Total Carbon, Organic Carbon, and Organic Matter. In: Sparks, D.L., Ed., Methods of Soil Analysis Part 3: Chemical Methods, 2nd Edition, SSSA, Madison, 961-1010.

[20] Batjes, N.H. (1996) Total Carbon and Nitrogen in the Soils of the World. European Journal of Soil Science, 47, 151-163. https://doi.org/10.1111/j.1365-2389.1996.tb01386.x

[21] Sisti, C.P.J., dos Santos, H.P., Kohhann, R., Alves, B.J.R., Urquiaga, S. and Boddey, R.M. (2004) Change in Carbon and Nitrogen Stocks in Soil under 13 Years of Conventional or Zero Tillage in Southern Brazil. Soil \& Tillage Research, 76, 39-58. https://doi.org/10.1016/j.still.2003.08.007

[22] Urquiaga, S., Alves, B.J.R., Jantalia, C.P. and Boddey, R.M. (2010) Variations in Soil Carbon Stocks and Greenhouse Gas Emissions in Tropical and Subtropical Regions of Brazil: A Critical Analysis. Informaçôes Agronômicas, 130, 12-21.

[23] Andreola, F., Costa, L.M. and Olszevski, N. (2000) Influence of Winter Plant Cover and Organic and, or, Mineral Fertilizer on the Physical Properties of a Structured Terra Roxa. Revista Brasileira de Ciência do Solo, 24, 857-865. https://doi.org/10.1590/S0100-06832000000400017

[24] Perin, A., Santos, R.H.S., Urquiaga, S., Guerra, J.G.M. and Cecon, P.R. (2004) Phytomass Yield, Nutrients Accumulation and Biological Nitrogen Fixation by Single and Associated Green Manures. Pesquisa Agropecuária Brasileira, 39, 35-40. https://doi.org/10.1590/S0100-204X2004000100005

[25] Gentry, L.E., Below, F.E., David, M.B. and Bergerou, J.A. (2001) Source of the Soybean N Credit in Maize Production. Plant Soil, 236, 175-184. https://doi.org/10.1023/A:1012707617126

[26] Sharrow, S.H. and Ismail, S. (2004) Carbon and Nitrogen Storage in Agroforests, Tree Plantations, and Pastures in Western Oregon, USA. Agroforestry Systems, 60, 123-130. https://doi.org/10.1023/B:AGFO.0000013267.87896.41

[27] Piva, J. (2012) Flow of Greenhouse Gases and Soil Carbon Stock in Integrated Systems Production in the Brazilian Sub-Tropics. Universidade Federal do Paraná, Curitiba.

[28] Carvalho, J.L.N., et al. (2010) Impact of Pasture, Agriculture and Crop-Livestock 
Systems on Soil C Stocks in Brazil. Soil \& Tillage Research, 110, 175-186. https://doi.org/10.1016/j.still.2010.07.011

[29] Lal, R. (2003) Global Potential of Soil Carbon Sequestration to Mitigate the Greenhouse Effect. Critical Reviews in Plant Sciences, 22, 151-184. https://doi.org/10.1080/713610854

[30] Drinkwater, L.E., Wagoner, P. and Sarrantonio, M. (1998) Legume-Based Cropping Systems Have Reduced Carbon and Nitrogen Losses. Nature, 396, 262-265. https://doi.org/10.1038/24376

[31] Amado, T.J.C., Bayer, C., Eltz, F.L.F. and Brum, A.C.R. (2001) Potential of Cover Crops to Sequester Carbon and Increase Soil Nitrogen Content, under No-Tillage System, Improving Environmental Quality. Revista Brasileira de Ciência do Solo, 25, 189-197. https://doi.org/10.1590/S0100-06832001000100020

Submit or recommend next manuscript to SCIRP and we will provide best service for you:

Accepting pre-submission inquiries through Email, Facebook, LinkedIn, Twitter, etc. A wide selection of journals (inclusive of 9 subjects, more than 200 journals)

Providing 24-hour high-quality service

User-friendly online submission system

Fair and swift peer-review system

Efficient typesetting and proofreading procedure

Display of the result of downloads and visits, as well as the number of cited articles Maximum dissemination of your research work

Submit your manuscript at: http://papersubmission.scirp.org/

Or contact as@scirp.org 